Article

\title{
Slow Fashion in a Fast Fashion World: Promoting Sustainability and Responsibility
}

\author{
Mark K. Brewer
}

Sheffield Business School, Sheffield Hallam University, Howard St, Sheffield S1 1WB, UK; mkb22@cornell.edu

Received: 23 July 2019; Accepted: 24 September 2019; Published: 9 October 2019

\begin{abstract}
Through its rapid production methods that supply the latest catwalk styles almost instantaneously to the high street, the fast fashion model has revolutionized the fashion industry, while generating a significant carbon footprint and a host of social concerns. Yet, the law is either slow or ineffective in promoting sustainability in a world obsessed with image and social connectivity, while outdated notions of companies continue to dominate the legal academy. This chapter initially examines the fashion industry's environmental footprint. Then, it examines the rise of the fast fashion model and law's inadequacy to prevent the model from undermining intellectual property rights or effectively address the model's detrimental impact on environmental and social sustainability. The chapter then challenges traditional notions of corporate personality, calling for more responsible corporate behavior and greater legal scrutiny. Finally, the chapter considers various issues to enhance ethical behavior in companies, arguing that the slow fashion movement provides an alternative paradigm to the fast fashion model, since the slow fashion movement connects suppliers and producers more closely with consumers, thereby enhancing sustainability and corporate responsibility.
\end{abstract}

Keywords: fashion law; fast fashion; sustainability; corporate social responsibility

\section{Introduction}

Perhaps more than almost any other field of art and industry, fashion is inextricably woven with time, finding its essence in current, fast-moving trends and its inspiration in emerging styles. With its rapid production times and ability to capture the latest, hottest trends, the fast fashion model of production, distribution, and marketing has thrived over the past decade. From production advances in textile factories to 3D printing (or additive manufacturing), technological changes have revolutionized production methods, allowing manufacturers to create garments increasingly fast. Aside from production advances in textile factories, 3D technology has the potential to render time an increasingly negligible element of the production cycle. Further, the democratization of fashion, spurred by cheaper garments, allowing companies to market to the masses, contributes to a throw-away culture and insatiable consumer demand for the latest knock-offs of the season's "it" pieces. Additionally, the prevalence of social media fuels the virtually instantaneous movement of trends within communities and networks across the world. From the carbon footprint inherent in a supply chain spanning the globe to the reliance on enormous quantities of natural resources, the impact on society and the environment of these trends has become increasingly clear. Yet, in a world obsessed with image and social connectivity—and driven by ever-changing consumer whims, there are no quick fixes to make the fashion industry more sustainable.

This chapter examines the environmental and social impact of fast fashion and the limits of the law to respond to these challenges. Against these constraints, the chapter makes the case for supporting the emerging slow fashion movement as well as other initiatives that connect suppliers and producers more closely with consumers. First, the chapter examines the staggering environmental impact of the fashion industry and critically analyzes the so-called "fashion paradox" or the relationship between 
the fashion industry's reliance on ever-changing styles and issues of sustainability. The chapter then presents the fast fashion industry, critically evaluating its business model and the legal limitations to enhancing sustainability in the fast fashion industry. Further, the chapter considers the effectiveness of corporate social responsibility as well as other soft law initiatives. Then, the chapter analyzes corporate personality and the impact that the law plays in skewing companies away from sustainable behavior, particularly in the fast fashion industry. Finally, the chapter argues that sourcing, production, and marketing practices that connect raw materials, designers, labor, and retailers more closely with consumers-key ingredients of the slow fashion movement-greatly enhance sustainability, protect human rights, and empower communities.

\section{Discussion}

\subsection{Fashion's Environmental Footprint}

Fashion is among the world's most polluting industries: it requires enormous quantities of raw materials, creates considerable levels of pollution, leaves a significant carbon footprint, and generates alarming levels of waste. According to the World Wildlife Fund (2019), 20,000 liters of water are required to produce one kilogram of cotton. Further, the textile industry produces enormous amounts of industrial waste, with some estimates suggesting that the industry contributes $17-20 \%$ of global industrial water pollution (Kant 2012). Additionally, industrial waste water from the textile industry often contains high levels of dangerous dyes and other chemicals, which may be toxic to aquatic wildlife and harmful to human health, particularly as a number of dyes are known to contain carcinogens that have been shown to cause several cancers (Ghaly et al. 2014).

Beyond its harmful impact on water supplies, the global fashion industry accounts for $10 \%$ of the world's carbon emissions, with significant emissions through both production and its supply chain (Conca 2015). In the production of fibers and textiles, the industry produced an estimated 1.2 billion tons of greenhouse emissions in 2015, exceeding the combined carbon footprint of international flights and maritime shipping (Ellen Macarthur Foundation 2017). Further, reliance on complicated supply chains spanning the globe and "just-in-time" production cycles means that fashion companies drive a high-carbon transport network in which raw materials travel from one country to another as they evolve into the garments that ultimately end up in shops around the world.

In addition to the detrimental impact of manufacturing and transporting products, our disused and unwanted clothing is creating ever larger rubbish heaps, as society is consuming, hoarding, and discarding new garments at unprecedented levels. In the United States, the Environmental Protection Agency's most recently available estimates indicate that 11.9 million tons of clothing and footwear were discarded in 2015, of which 8.2 million tons ended up in landfills (Environmental Protection Agency 2019). Moreover, several large fashion companies such as Burberry have been accused of disposing of large quantities of new merchandise (House of Commons Environmental Audit Committee 2019), not only contributing to high levels of waste but also raising serious concerns about the ethical, social, and environmental aspects of such practices. As customers and other stakeholders more fully understand the adverse environmental impact of our throw-away clothing culture, they are increasingly demanding that companies modify their behavior to minimize their damage to the environment, with research suggesting that greater knowledge of unsustainable practices by companies influences customer behavior and judgments (Grappi et al. 2017).

Unlike natural fibers such as cotton or wool, synthetic fibers such as polyester, rayon, or nylon may take up to 200 years (or more as explained below) to decompose. The scale of devastation caused by microfibers or tiny synthetic fiber used in clothing, upholstery, and other materials is staggering, with scientists estimating that microfibers make up $85 \%$ of human-made debris on ocean shorelines (Browne 2011). Moreover, polyethylene terephthalate (PET), commonly called polyester in the textile industry and the largest segment of the synthetic fiber sector, has a particularly slow rate of decomposition, with some scholars suggesting a single PET bottle may take approximately 
800-1000 years to decompose in natural conditions (Zengin et al. 2016). As the textile industry consumes the majority of PET globally (more than plastic bottles and other PET products combined) (Shen et al. 2012), this source of microfibers is particularly harmful to the environment. Indeed, an increasing body of literature suggests that microfibers have now entered the human food chain not only through the consumption of fish and other aquatic life but more disturbingly through drinking water as well (Henry and Klepp 2019). The fashion industry's consumption of enormous quantities of raw materials, production of dangerous levels of pollution, creation of a significant carbon footprint, and generation of alarming levels of waste all pose particular problems to environmental sustainability.

Moreover, the so-called fashion paradox, or the relationship between the fashion industry's imperative to continually evolve to satisfy consumers' insatiable desire to acquire the most exclusive, latest trends, and the consequent loss of exclusivity as consumers acquire the most popular garments, suggests that the fashion industry's very raison d'être is inherently diametrically opposed to sustainability. While social critics may decry the inevitable inequality implicit in the very existence of fashion, the rise of fast fashion as discussed below has fundamentally democratized style through unleashing collection after collection of knock-off designs at minimum financial costs but significant environmental costs. Previously, the most exclusive and expensive garments were beyond the means of but the wealthiest; however, the advent of quick design processes, rapid production methods, and highly efficient supply chains to churn out garments has brought the latest styles to the masses virtually instantaneously (particularly when one considers the capability of 3D printing). Implicit in the fashion paradox is the contradiction between fashion's imperative to be "in style" with constant changes and new seasons versus sustainability and responsibility. The desire of consumers to remain "in fashion" requires a constant supply of new styles since once a new fashion goes mainstream, it becomes obsolete, losing its allure and encouraging trendsetters to search for the next new fad. Whether through globalization propelling ever-faster production cycles, the proliferation of online social media featuring the latest styles, internet influencers generating interest in new products, the burgeoning number of fashion shows internationally, or simply global economic growth, the public's addiction to ever-changing fashion fuels demand for higher carbon-producing modes of transport such as air freight, which often replace less polluting forms of transport such as shipping. Ultimately, the modern fashion cycle consumes massive quantities of raw materials and contributes an enormous carbon footprint through energy-intensive production methods and global supply chains.

\subsection{Fast Fashion}

The concurrent declining costs and increasing speed of production have provided the ideal environment for the "fast fashion" model which delivers to consumers copies of the latest trends, often before the originals themselves hit the stores (Beebe 2010). With such rapid production and quick, efficient supply chains, companies such as Zara, H\&M, Forever21, and Topshop have revolutionized the traditional fashion marketplace (Cline 2012). While these developments have had the positive effect of democratizing fashion, allowing a broad range of consumers to share in close copies of the most exclusive and expensive designers, the fast fashion model has undermined the value of intellectual property belonging to designers, dramatically expanded the industry's carbon footprint, and promoted a culture of waste. In contrast to the fashion industry's traditional focus on creating new designs, the fast fashion model is driven by trends and consumer behavior (Tokatli 2007) and focuses on providing lower cost garments that are either inspired or simply copied from the latest trends. Hence, many fast fashion companies have been accused of undermining the intellectual property of designers and weakening the incentive of consumers to spend money on more expensive original designs. As a result, the fast fashion model may actually discourage creativity and individuality as well as hamper new and emerging designers in favor of established brands which tend to set the trend for fast fashion copies as discussed below. 


\subsection{Limitations of the Law and Other Measures}

The law often only offers limited protection to intellectual property in the fashion industry, which may encourage fast fashion firms to disregard intellectual property law. Large, well-known fashion brands, such as Gucci, Adidas, and Puma, have the influence and resources to challenge intellectual property infringements, and indeed, such brands have challenged alleged infringements from the fast fashion companies such as Foreover21. However, the opportunity cost of such expensive litigation may ultimately result in higher prices on the racks and lower salaries in the industry. Further, new and emerging designers initially may struggle to achieve visibility among the cheaply made, mass-marketed fast fashion collections, and if their designs are indeed misappropriated by fast fashion firms, new and emerging designers often lack the resources to challenge intellectual property theft. In short, the tendency of fast fashion companies to mimic traditional designers poses real threats to the integrity, value, and viability of other designers. This legal lacuna not only allows for unjustified copying of designs but also tacitly promotes the fast fashion business model's wasteful approach to natural resources as well as its reliance on carbon-intensive supply chains and production methods. Further, social media's ability to spread new fads globally almost instantaneously, combined with rising levels of disposal income (particularly in rapidly growing developing countries) drives the insatiable consumer demand for cheap knock-off styles. This, in turn, further fuels the fast fashion industry's substantial carbon footprint.

An extensive network of national laws, international standards, and best industry practices regulate labor conditions. At the international level, the International Labor Organization provides a forum to promote appropriate standards, policies, and programs to protect the rights of workers. Additionally, the G7 has formulated due diligence standards for the textile industry to help improve working conditions and enhance workers' rights in the global textile supply chain. Nonetheless, many harsh conditions persist. The April 24, 2013 collapse of the eight-story Rana Plaza building in Savar Upazila in Greater Dhaka, Bangladesh, epitomizes the devastating impact of poor working conditions in the garment industry. Ignoring warnings on the day prior to the collapse, factory managers ordered garment workers to report for work or their pay would be docked, although a bank and shops on the lower floors of the building were closed in response to the concerns over the building's integrity. The collapse caused the death of 1134 people and injured approximately 2500 others (Ansary and Barua 2015).

In response to concern over working conditions and labor standards in supply chains, there is an increasing emphasis on transparency in supply chains and traceability of raw materials used in producing clothing. While various legal provisions, such as Section 1502 of the Dodd-Frank Wall Street Reform and Consumer Protection Act in the United States, the California Transparency in Supply Chains Act of 2010, and the Modern Slavery Act 2015 in the U.K., all require disclosure of supply chain details, other forms of so-called "soft law" such as voluntary codes also guide or encourage companies to adhere to higher standards in their supply chains. Indeed, de Brito et al. (2008) demonstrate that companies may not only be compelled by legal requirements, but they may also engage in more ethical behavior through seeking a competitive advantage or through pursuing policies of corporate social responsibility; however, the authors also acknowledge that companies face much ambiguity in determining the demands of various stakeholders. Moreover, many "soft law" guidelines are limited, as they often rely on voluntary adherence or lack effective enforcement mechanisms. Nonetheless, through such initiatives that promote sustainability and corporate social responsibility, many companies increasingly choose to adopt policies and practices that are intended to respect social, environmental, ecological, and economic issues locally and globally. However, why do some companies prioritize sustainability while others do not? 


\subsection{Creating a Better Company}

Given the variety of individuals and businesses involved in the fashion industry, it is difficult to generalize on the personality of such entities; yet, collectively, they exert an enormous influence on society and the environment. Companies such as Benetton have been innovators in promoting social issues, while Vivienne Westwood and Stella McCartney have become almost synonymous with sustainable fashion and social responsibility. Despite these well-known champions of sustainability, the industry at large exerts a substantial detrimental impact on the environment and society. The question arises why do so many fashion companies have such a detrimental impact on the environment, while certain other fashion companies champion sustainability? The answer most likely lies in the dichotomy of cheap prices demanded by consumers and ethical concerns of the public, together with differing models of corporate personality.

Further, prevailing concepts of corporate personality may straightjacket fashion companies into maximizing short-term corporate profits over other considerations. To explain, economists and legal scholars have long focused on rights and duties of shareholders in an attempt to explain the purpose of corporations, with two distinct views of corporate personality emerging. The dominant view in Anglo-American law, which focuses on shareholder value and shareholder primacy over other considerations, has driven short-term profits at the expense of other stakeholders, thereby accelerating global warming and rising sea levels over the past few decades. In contrast, more enlightened views of the purpose of corporations stress the importance of a wide variety of stakeholders, allowing companies to weigh longer-term considerations in making decisions. Each of these models is presented below.

Tracing its origins to the pioneering research of Berle and Means (1932) as well as Michael Jensen and William Meckling's seminal work "Theory of the Firm: Managerial Behavior, Agency Costs and Ownership Structure" (Jensen and Meckling 1976), shareholder value theory is epitomized by Friedman (1962) in his frequently quoted statement: "There is one and only one social responsibility of business- to use its resources and engage in activities designed to increase its profits so long as it stays within the rules of the game, which is to say, engage in open and free competition, without deception or fraud." Under such a construction, the interests of shareholders are paramount to all other stakeholders, which includes employees, customers, and the communities in which the company is active. Indeed, scholars espousing such a rigid view of companies point to seminal U.S. Supreme Court cases such as Dodge v. Ford ${ }^{1}$, Schlensky v. Wrigley ${ }^{2}$, and Revlon, Inc. v. Forbes Holdings ${ }^{3}$ as authority for the argument that companies must concentrate on the maximization of shareholder value, which often means ignoring other stakeholders that affect the company's long-term impact as companies pursue short-term profits at the expense of long-term stability, including the impact on local communities, labor, the environment, and other stakeholders. In contrast to such a rather myopic view of corporations, a number of other scholars (Stout 2012; Rotman 2010) have convincingly displayed the shareholder maximization model's "shaky foundation" and have argued that the case law cited in favor of the shareholder value theory is not as clearly supported as often assumed in the prevailing academic literature (Lee 2009) nor do any corporate statutes or legal decisions require companies to strictly follow the shareholder maximization model (Sneirson 2011). Moreover, it is absurd to argue that companies best serve society by simply ignoring all but corporate profits (Greenfield 2005).

Further, as legal persons, companies enjoy a number of rights and privileges-it is only fitting and right that they should also have at least moral and ethical obligations to consider the impact of their actions upon their various stakeholders beyond their shareholders. While society demands a range of ethical behavior from natural persons, the basic legal structure of corporations removes personal responsibility from decision-makers and characteristically limits liability for the business to the capital

Dodge v. Ford Motor Co. 170 N.W. 668, 684 (Mich. 1919).

Schlensky v. Wrigley, 95 Ill. App. 2d 173, 237 N.E.2d 776 (App. Ct. 1968).

Revlon, Inc. v. MacAndrews \& Forbes Holdings, Inc., 506 A.2d 173 (Del. 1986). 
it holds. Unlike natural persons who may be liable for tortious conduct, the corporate form insulates the individuals who may reach decisions leading to tortious conduct by the corporation, with liability for wrong-doing largely limited to the corporate level, rather than the actual decision-makers who devised, implemented, or took the actions that caused the harmful result. The diffused constellation of decision-making, control, and liability may encourage managers-who may be protected by indemnities in corporate charters-to engage in "excessive levels of risk-taking," which they would avoid in their capacity as individual persons (Ho 2013). Herein lies the so-called agency-principal problem (Jensen and Meckling 1976), which denotes the manner in which the board of managers makes decisions for the corporation and exercises control with limited oversight by its shareholders who are dispersed and meet only periodically. Moreover, the law often protects corporate boards from liability for their decisions through the business judgment rule, a concept that U.S. courts developed but now exists in various forms in other jurisdictions, including the U.K., Canada, and much of the common law world. Accordingly, courts will routinely disregard shareholder challenges if the board can identify a business purpose for such decision where the board acted in the company's best interest and in good faith with the due care of a reasonably prudent person. Absent from this analysis is the impact of decisions on the environment, the local community, consumers, the public, employers, workers in supply chains, and a host of other stakeholders. Therefore, a number of scholars have argued that the business judgment rule may often weigh in the favor of the directors at the expense of other stakeholders (Gevurtz 2011; Dibadj 2005). Yet, a more enlightened view of the shareholder value theory recognizes a broader range of stakeholders and doing so may actually enhance shareholder value. Further, a mechanical application of the business judgment rule dismisses the larger social impact that business decisions have and the detrimental impact they may exert when executed without due consideration of the larger consequences of the decision. Similarly, directors in the U.K. have a duty to manage the company in the interest of shareholders, as held in Percival v. Wright ${ }^{4}$ (1902) and codified in the Companies Act 2006. In contrast to U.S. law, however, Parliament specifically introduced the concept of "enlightened shareholder value" in the Companies Act 2006, which requires directors to consider the collective best interest of shareholders in the context of other stakeholders, including employees as well as the environment. Despite criticisms that these U.K. reforms have not lived up to expectations, the emphasis on enlightened shareholder value does introduce the imperative that companies consider other stakeholders when setting policy and making decisions.

In contrast to an extreme interpretation of the shareholder value theory which seeks to maximize shareholder wealth without regard to other stakeholders, the concept of corporate social responsibility (CSR) encourages companies to develop sustainable policies and reach decisions with due regard to the environment and society, taking into consideration a much broader range of stakeholders than simply the company's shareholders. While CSR standards are often voluntary, they may help modify behavior by raising awareness and generating consumer pressure on other companies to follow the higher ethical standards of leading competitors. Essentially, CSR not only makes sense ethically, but it is often good business. In particular, the world's top 20 companies according to revenue have all adopted some type of CSR report, and as previously mentioned, well-known designers such as Vivienne Westwood and Stella McCartney have helped to pioneer responsible policies in the fashion industry. Nevertheless, it must be acknowledged that CSR lacks the force of mandatory law and may even in some circumstances inhibit mandatory law containing higher standards where companies adopt voluntary CSR initiatives.

\subsection{Slow Fashion: Enhancing Sustainability, Protecting Human Rights, and Empowering Communities}

On the opposite end of the spectrum from the fast fashion model of production, Kate Fletcher (2007) founded the slow fashion movement by drawing inspiration from the "slow food" movement, which

4 Percival v. Wright, [1902] 2 Ch. 421. 
emphasizes responsibility in food production and consumption. Companies that emphasize more sustainable practices make up the slow fashion movement, prizing craftsmanship, good stewardship, and quality products. Therefore, they naturally promote sustainability through more ethical sourcing and production techniques as well as by using organic, recycled, or more durable materials. Further, the labor involved in the production of such garments receives higher wages and greater protection than its counterparts in the supply chain of the fast fashion industry. While finished garments may cost more, they last longer and incorporate more timeless styles that do not go "out of fashion." Through a greater emphasis on connecting raw materials, designers, artisans, retailers, and consumers, firms in the slow fashion movement promote sustainability in sourcing, production, and consumption. However, the slow fashion movement faces an uphill battle with cheap, knock-off designs massed-marketed in a world of increasing consumer appetite. Therefore, government policies, reorientation of supply chains, and greater consumer knowledge and engagement are all necessary to level the playing field between fast and slow fashion.

In response to the types of concerns discussed above, a number of organizations attempt to raise public awareness, report on the adverse impact of supply and production methods, and provide registers of raw materials sourced and produced in an ethical and sustainable manner. In particular, the Fairtrade Foundation promotes social, economic, and environmental standards across a number of agricultural products and raw materials, including bananas, coffee, tea, chocolate, cut flowers, gold, wine, and cotton. It also promotes other activities to enhance worker rights, promote fair wages, and develop communities in regions supplying such products. With respect to items of fashion, labelling schemes for fair-trade cotton like that of the Fairtrade Foundation may provide consumers with greater assurance that the sourcing and production methods allow for better and more stable incomes (Fairtrade Foundation 2019). In addition to fair-trade sourcing and production, labelling of organic cotton provides consumers with assurance that the cotton has been produced in a manner that has a lower impact on the environment by limiting the use of pesticides and fertilizers and utilizing non-modified plants. The Global Organic Textile Standard (GOTS) provides a global means to identify and promote organic textiles, including the raw materials, manufacturing processes, and labelling of products. By focusing on the complete supply chain of textiles, the GOTS provides end users assurance through independent certification that the textiles have been sourced and manufactured in adherence with relevant social and ethical criteria (Global Organic Textile Standard 2018).

Founded in 1998, the U.K.-based Ethical Trading Initiative works with its member organizations, including companies, trade unions, and NGOs, to promote international labor rights by promoting employees' freedoms and safe working environments, eradicating child labor, ensuring the payment of living wages, curtailing excessive working hours and harsh treatment, eliminating discrimination, and encouraging regular and legal employment relationships (Ethical Trading Initiative 2019). With respect to the fashion industry in particular, the ETI has promoted initiatives to improve working conditions in garment production.

Aside from these initiatives, the discussion above on corporate personality illustrates the importance of companies embedding sustainability in their sourcing, production, and interaction with consumers. Nonetheless, consumer interest in sustainable fashion has not necessarily resulted in changes in consumer behavior. For example, Sudbury and Böltner (2011) have shown that consumers may choose lower prices instead of higher standards of sustainability, even when such consumers have a greater awareness of ethical fashion. Therefore, slow fashion companies must more effectively convey to consumers the cost of cheap fashion vis-à-vis fast fashion. Additionally, they must continue to emphasize slow fashion's responsible practices and contributions to sustainability, thereby helping to guide consumer knowledge toward a reorientation away from fast fashion to more sustainable types of design, sourcing, production, and marketing. Moreover, government policies, industry bodies, and other stakeholders must work with the industry to highlight the advantages of slow fashion, while discouraging the excesses of fast fashion. 


\section{Conclusions}

The global fashion industry faces a number of challenges in terms of sustainability and social responsibility. In particular, the fast fashion model generates a significant carbon footprint and raises a number of social and environmental concerns. Given that the law currently provides only limited protection of rights in the fashion industry and is often ineffective in improving corporate behavior, corporate social responsibility and sustainability initiatives may help to combat inequality in the fashion industry as well as improve standards and conduct. Therefore, legal reforms and increased support for companies that pursue more sustainable practices are necessary to reorient the fashion industry and consumers away from the fast fashion model toward more sustainable sourcing, production, distribution, marketing, and consumption practices. Companies that adopt such slow fashion practices should provide a template for the future of the global fashion industry.

Funding: This research received no external funding.

Conflicts of Interest: The author declares no conflict of interest.

\section{References}

Ansary, Mehedi Ahmed, and Uttama Barua. 2015. Workplace safety compliance of RMG industry in Bangladesh: Structural assessment of RMG factory buildings. International Journal of Disaster Risk Reduction 14: 424-37. [CrossRef]

Beebe, Barton. 2010. Intellectual Property Law and the Sumptuary Code. Harvard Law Review 123: 834-35.

Berle, Adolph A., Jr., and Gardiner C. Means. 1932. The Modern Corporation and Private Property. New York: The MacMillan Company.

Browne, Mark Anthony. 2011. Accumulation of Microplastic on Shorelines Worldwide: Sources and Sinks. Environmental Science \& Technology 45: 9175-79. [CrossRef]

Cline, Elizabeth L. 2012. Over-Dressed: The Shockingly High Cost of Cheap Fashion. New York: Penguin, p. 96.

Conca, James. 2015. Making Climate Change Fashionable-The Garment Industry Takes on Global Warming. Available online: https://www.forbes.com/sites/jamesconca/2015/12/03/making-climate-change-fashionablethe-garment-industry-takes-on-global-warming/\#18725edb79e4 (accessed on 8 October 2019).

de Brito, M., Valentin Carbone, and Corinne Meunier Blanquart. 2008. Towards a sustainable fashion retail supply chain in Europe: Organisation and performance. International Journal of Production Economics 114: 534-53. [CrossRef]

Dibadj, Reza. 2005. Delayering Corporate Law. Hofstra Law Review 34: 477.

Ellen Macarthur Foundation. 2017. A New Textiles Economy: Redesigning Fashion's Future. Cowes: Ellen Macarthur Foundation, p. 2. Available online: https://www.ellenmacarthurfoundation.org/assets/downloads/publications/ A-New-Textiles-Economy_Full-Report_Updated_1-12-17.pdf (accessed on 8 October 2019).

Environmental Protection Agency. 2019. Facts and Figures about Materials, Waste and Recycling. Available online: https://www.epa.gov/facts-and-figures-about-materials-waste-and-recycling/nondurable-goodsproduct-specific-data (accessed on 8 October 2019).

Ethical Trading Initiative. 2019. Available online: https://www.ethicaltrade.org/about-eti (accessed on 8 October 2019). Fairtrade Foundation. 2019. Available online: http://www.fairtrade.org.uk (accessed on 8 October 2019).

Fletcher, Kate. 2007. Slow fashion. The Ecologist 37: 61.

Friedman, Milton. 1962. Capitalism and Freedom. Chicago: University of Chicago Press, pp. 124-33.

Gevurtz, Franklin A. 2011. The Globalization of Corporate Law: The End of History or a Never-Ending Story. Washington Law Review 86: 518.

Ghaly, Andrew, Rishi Ananthashankar, Mohammed Kadhim Alhattab, and Varsha Ramakrishnan. 2014. Production, Characterization and Treatment of Textile Effluents: A Critical Review. Journal of Chemical Engineering Process Technology 5: 11.

Global Organic Textile Standard. 2018. Ecology \& Social Responsibility. General Description. Available online: https://www.global-standard.org/the-standard/general-description.html (accessed on 8 October 2019). 
Grappi, Silvia, Simona Romani, and Camilla Barbarossa. 2017. Fashion without pollution: How consumers evaluate brands after an NGO campaign aimed at reducing toxic chemicals in the fashion industry. Journal of Cleaner Production 149: 1164-73. [CrossRef]

Greenfield, Kent. 2005. New Principles for Corporate Law. Hastings Business Law Journal 1: 91.

Henry, Beverley, and Ingun Grimstad Klepp. 2019. Microfibres from apparel and home textiles: Prospects for including microplastics in environmental sustainability assessment. Science of The Total Environment 652: 483-94. [CrossRef] [PubMed]

Ho, Virginia Harper. 2013. Of Enterprise Principles and Corporate Groups: Does Corporate Law Reach Human Rights? Columbia Journal of Transnational Law 52: 113-72.

House of Commons Environmental Audit Committee. 2019. Fixing Fashion: Clothing Consumption and Sustainability, Sixteenth Report of Session 2017-19, HC 1952, 19 February 2019. pp. 44-45. Available online: https://publications. parliament.uk/pa/cm201719/cmselect/cmenvaud/1952/1952.pdf (accessed on 25 March 2019).

Jensen, Michael C., and William H. Meckling. 1976. Theory of the Firm: Managerial Behavior, Agency Costs and Ownership Structure. Journal of Financial Economics 3: 305-60. [CrossRef]

Kant, Rita. 2012. Textile dyeing industry an environmental hazard. Natural Science 4: 22-26. [CrossRef]

Lee, Ian B. 2009. Citizenship and the Corporation. Law \& Social Inquiry 34: 129-68.

Rotman, Leonard I. 2010. Debunking the 'End of History' Thesis for Corporate Law. Boston College International $\mathcal{E}$ Comparative Law Review 33: 219-72.

Shen, Li, Ernst Worrell, and Martin K. Patel. 2012. Comparing life cycle energy and GHG emissions of bio-based PET, recycled PET, PLA, and man-made cellulosics. Biofuels Bioproducts and Biorefining 6: 625-39. [CrossRef]

Sneirson, Judd F. 2011. The Sustainable Corporation and Shareholder Profits. Wake Forest Law Review 46: 541.

Stout, Lynn. 2012. The Shareholder Value Myth: How Putting Shareholders First Harms Investors, Corporations, and The Public. San Francisco: Berrett-Koehler Publishers.

Sudbury, Lynn, and Sebastian Böltner. 2011. Fashion Marketing and the Ethical Movement Versus Individualist Consumption: Analysing the Attitude Behaviour Gap. E - European Advances in Consumer Research. Edited by Alan Bradshaw, Chris Hackley and Pauline Maclaran. Duluth: Association for Consumer Research, vol. 9, pp. 163-68.

Tokatli, Nebahat. 2007. Global Sourcing: Insights from the Global Clothing Industry-The Case of Zara, a Fast Fashion Retailer. Journal of Economic Geography 8: 21-38. [CrossRef]

World Wildlife Fund. 2019. Sustainable Agriculture. Cotton. Available online: https://www.worldwildlife.org/ industries/cotton (accessed on 8 October 2019).

Zengin, Huseyin, Amine Cicek, and Gulay Zengin. 2016. Recovery of Polyethylene Terephthalate (PET) based waste polymers, polyester fiber production phases, and chemical and chain extenders. Paper presented at International Engineering, Science and Education Conference, Diyarbakir, Turkey, December 1-3.

(C) 2019 by the author. Licensee MDPI, Basel, Switzerland. This article is an open access article distributed under the terms and conditions of the Creative Commons Attribution (CC BY) license (http://creativecommons.org/licenses/by/4.0/). 